\title{
Correction to: Adaptors as the regulators of HECT ubiquitin ligases
}

\section{Sonia Shalini Shah · Sharad Kumar(D)}

Published online: 22 January 2021

(c) The Author(s), under exclusive licence to ADMC Associazione Differenziamento e Morte Cellulare 2021

Correction to: Cell Death \& Differentiation

https://doi.org/10.1038/s41418-020-00707-6

Published online 05 January 2021

The original version of this article unfortunately contained a mistake in Fig. 2. The correct figure can be found below. The original article has been corrected.

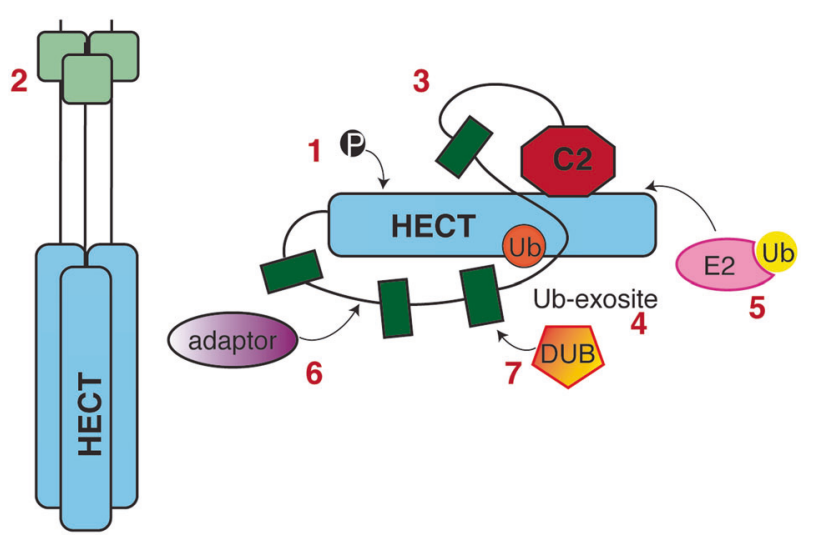

Fig. 2 